\title{
Purification of specific precipitinogen and extraction of endotoxin from Haemophilus influenzae 1
}

\author{
J. C. VAN DER ZWAN, J. DANKERT, K. DE VRIES, N. G. M. ORIE, AND \\ H. F. KAUFFMAN \\ From the University Hospital, Groningen, The Netherlands
}

SUMMARY After purifying a Haemophilus influenzae precipitinogen from endotoxic activity by means of ultracentrifugation, column chromatography (Sepharose 6B), and ion exchange chromatography (DEAE Sephadex A25) a fraction was obtained which still contained a specific precipitinogen that was virtually free of endotoxin. Furthermore, during the chromatographic procedures fractions with a high and a low molecular weight endotoxic activity were found. The limulus lysate test was more sensitive in the high molecular weight fractions and the $\mathrm{LD}_{50}$ in mice in the low molecular weight fractions with endotoxic activity.

The non-encapsulated Haemophilus influenzae (HI) is the most common pathogen in the bronchial tree of patients with chronic non-specific lung disease (CNSLD) (Mulder, 1938; Brumfitt et al., 1957). When the effect of $H$. influenzae precipitinogen in skin test and bronchial provocation was studied it was difficult to differentiate between an immunological and a toxic mechanism in the reaction to the test substance (van der Zwan et al., 1975). It has been suggested that endotoxin is present in $H$. influenzae (Branefors-Helander, 1973; Denny, 1974; van der Zwan et al., 1975). A lipopolysaccharide has recently been isolated from $H$. influenzae and defined chemically (Zoon and Scocca, 1975). Therefore a specific precipitinogen, as defined by Omland (1964) and May (1965), without endotoxic activity and also a purified endotoxin is necessary in order to be able to identify the immunological and toxic reaction separately.

A purified precipitinogen is obtained by the methods described below. For extracting lipopolysaccharides from rough growing bacteria the method described by Galanos et al. (1969) was used. The limulus lysate test (LLT) was used to measure the endotoxic activity of the extracts, because it is relatively easy to perform and highly sensitive. An in-vivo system was required since the bacterial compounds were to be used in man. For that purpose the mortality in mice after potentiation with actinomycin-D was used (Pieroni et al., 1970).

1Dedicated to the late Professor J. R. May

Received for publication 28 September 1977

\section{Methods}

CULTURE

A rough growing, non-encapsulated strain of $H$. influenzae from a patient with chronic purulent bronchitis (confirmed by The Netherlands National Health Laboratory Service, strain number BBD 5048) was cultured at $37^{\circ} \mathrm{C}$ on Levinthal plates (Oxoid Ltd). After 24 hours the micro-organisms were transferred to a Microform Fermentor (New Brunswick Scientific Co) containing 121 Levinthal broth. The inoculum was cultured for 20 hours at $37^{\circ} \mathrm{C}$ with an aeration of $1 \mathrm{l} / \mathrm{min}$ and stirred at 100 $\mathrm{rpm}$. By taking samples from the culture at intervals of four hours it was shown that the $\mathrm{pH}$ remained between $7 \cdot 1$ and $7 \cdot 4$. Control of the culture was checked by a Gram stain and by culture on Levinthal and blood-agar plates (Oxoid Ltd). After centrifugation of the culture at $1900 \mathrm{~g}$ for 15 minutes the residue was washed three times in $12.5 \mathrm{mmol}$ (6.25 mEq/l) $\mathrm{MgCl}_{2}$ to remove the remaining broth. The weight of the pellet was considered to be the wet weight of the bacteria.

\section{IMMUNOLOGICAL METHODS}

Precipitinogens in the different fractions were identified by immunodiffusion according to Ouchterlony (1962). When the immunodiffusion was positive immunoelectrophoresis was performed by the method of May (1968), which detects antibody to the specific and non-specific antigens of $\boldsymbol{H}$. influenzae. The sera used were from patients with CNSLD who had $\boldsymbol{H}$. influenzae in their sputum. The 
sera contained either specific or non-specific, or both, precipitins against $H$. influenzae (May, 1968).

\section{ENDOTOXIN DETECTION}

Localisation of endotoxin was attempted by staining on the immunoelectrophoresis slide, using Sudan black for the lipid and Shiff's reagent for the saccharide moiety of the endotoxin (Uriel, 1964).

The LLT was used for in-vitro activity (RojasCorona et al., 1969). The result was read after two hours and considered to be positive when a firm gel had been formed.

In-vivo endotoxic activity was studied in female Swiss mice, weighing between 15 and $25 \mathrm{~g}$, by using the potentiating effect of actinomycin-D (Pieroni et al., 1970). The $\mathrm{LD}_{50}$ was estimated by the method of Reed and Muench (1938). To compare the content of endotoxin in the different preparations end-point titrations were carried out according to Jorgensen and Smith (1974). A reference endotoxin from Escherichia coli had an end-point titration at $10^{-7} \mathrm{mg} / \mathrm{ml}$ solvent.

\section{ENDOTOXIN EXTRACTION}

The method of extracting endotoxin, which is specially suited for rough-growing bacteria, was by using a monophasic extraction mixture consisting of aqueous phenol, chloroform, and petroleum ether (Galanos et al., 1969).

The fractionating procedure was as depicted in Fig. 1.

\section{EXTRACT PREPARATION}

The bacteria were disrupted by ultrasonic disintegration (MSE) as described by May (1968) using a buffer of $12.5 \mathrm{mmol}(6.2 \mathrm{mEq} / \mathrm{l}) \mathrm{MgCl}_{2}$ to stabilise the endotoxin in its high molecular weight form (Greer et al., 1973). Ultracentrifugation was carried out at $200000 \mathrm{~g}$ for 30 minutes to remove all particle-bound endotoxin. Since the supernatant still had considerable endotoxic activity a further separation was tried by means of chromatographic procedures.

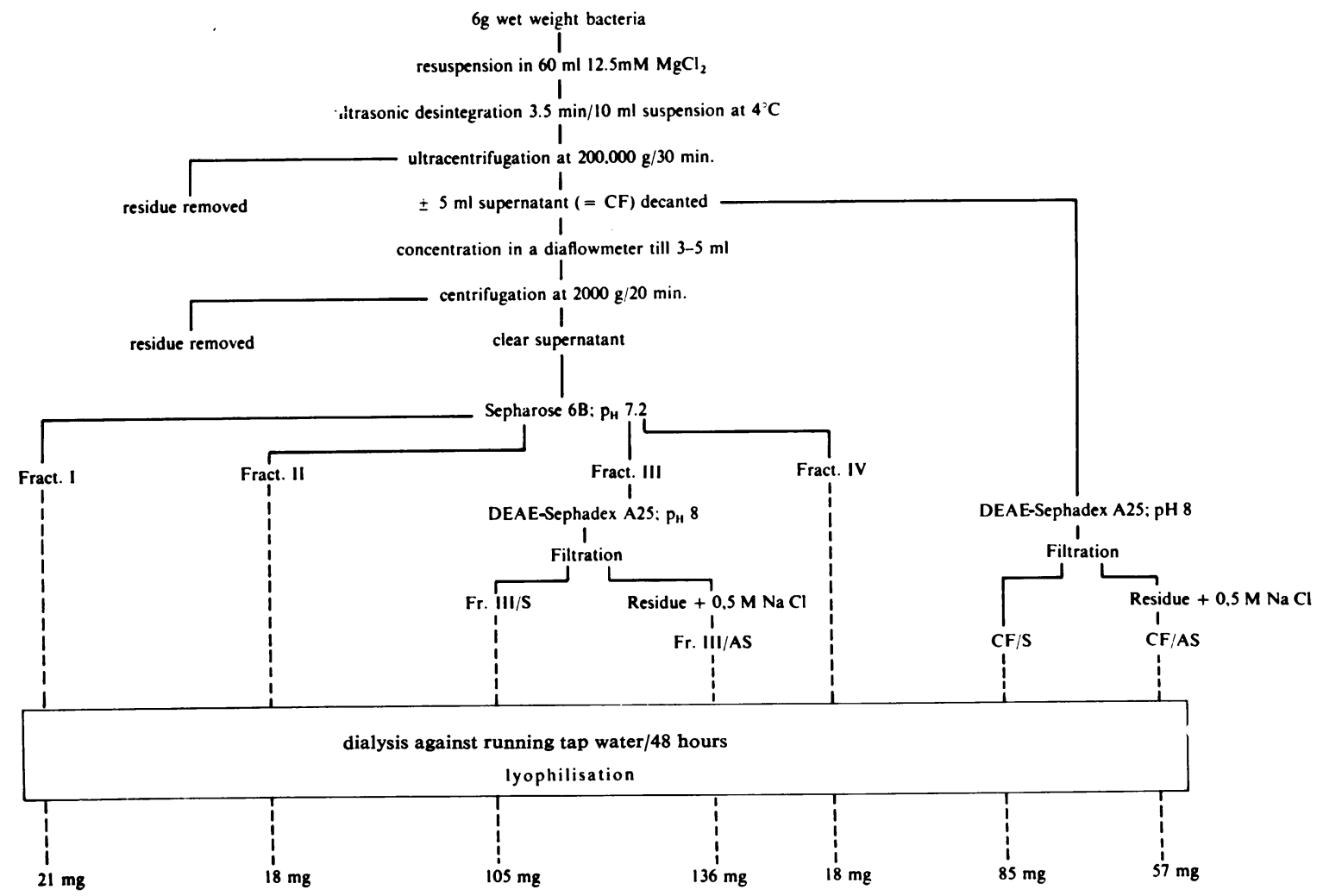

Fig. 1 Diagram of fractionating procedures. 
CHROMATOGRAPHY

Column chromatography was carried out using Sepharose 6B as a carrier (column diameter $2.5 \mathrm{~cm}$, volume $450 \mathrm{ml})$. The supernatant obtained after ultracentrifugation was concentrated in a diaflowmeter with a filterpore of $10 \mathrm{~m} \mu$ to a volume of 3-5 $\mathrm{ml}$. This concentrate was centrifuged at $2000 \mathrm{~g}$ for 20 minutes to remove denaturated material and was brought on the column. The eluate was sampled by means of a LKB fraction collector and measured at $276 \mathrm{~nm}$ by an Uvicord (LKB). After chromatography the eluate was pooled as follows: fraction $I$ $( \pm 60 \mathrm{ml})$, fraction II $( \pm 36 \mathrm{ml})$, fraction III $( \pm 132$ $\mathrm{ml}$ ), and fraction IV ( $\pm 78 \mathrm{ml}$ ), (Fig. 2). The place of the absorption maxima of the fractions were reproducible for different batches, although the sharpness of the peaks differed slightly. In addition ion exchange chromatography was performed using DEAE-Sephadex A25 (Davies et al., 1974). The pooled fractions were dialysed during 48 hours against running tap-water and lyophilised.

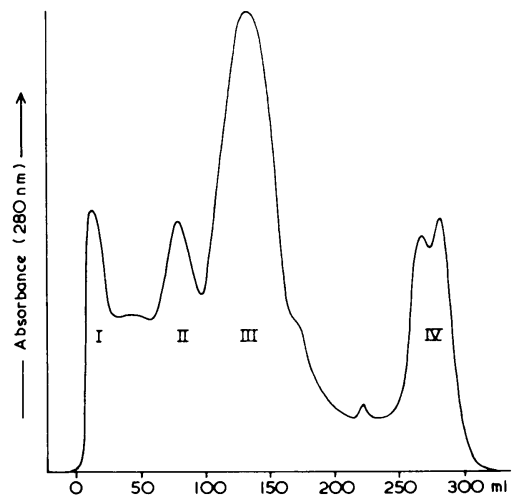

Fig. 2 Absorption maxima after passage of particle-free cytoplasmic fraction of $\mathrm{H}$. influenzae via a column with Sepharose $6 B$.
CHEMICAL ANALYSIS

The fractions were characterised according to their protein, lipid, and carbohydrate content. The amount of the protein in the various fractions was estimated by the method of Lowry (Lowry et al., 1951). The lipid content of the unsaturated moiety was assessed as described by Hoeflmayr (Hoeflmayr and Fried, 1967). For the estimation of saturated fatty acids the fractions were extracted in chloroform and dried in a nitrogen stream. For the thin-layer chromatography Kieselgel (Merck Ltd) was used (thickness $0.25 \mathrm{~mm}$ ). A mixture of petroleum ether $40 / 60$ and acetone in a ratio of $85: 15 \mathrm{v} / \mathrm{v}$ (Merck Ltd) was used for development. The results were read with ultraviolet light $(350 \mathrm{~nm})$ and graded from - to +++ . Anthrone reagent was used for detecting carbohydrate, which was quantified in amounts equivalent to galactose (Toennies and Kolb, 1964). When repeated the results varied by $5 \%$ to $12 \%$ for the protein and lipid content and by $5 \%$ to $18 \%$ for the carbohydrate.

\section{Evaluation of procedures and results}

PURIFICATION OF PRECIPITINOGEN

The whole $H$. influenzae bacterium showed a high endotoxic activity (Table 1) and was obviously negative in the precipitation tests. Since endotoxin is a component of the inner cell wall (de Petris, 1967) ultrasonic disintegration and ultracentrifugation were performed and a particle-free cytoplasmic fraction (CF) obtained. This was still considerably contaminated with endotoxin but it contained the specific and non-specific antigen, as was shown in the IEF (Table 1).

Since it could be expected that the endotoxin had a high molecular weight (Lüderitz et al., 1966) column chromatography was carried out. Fig. 2 shows the elution pattern of $3.5 \mathrm{ml}$ of the concentrated CF when brought on a Sepharose B6 column.

Table 1 Endotoxic activity (measured in vivo and in vitro) and precipitinogen content in the lyophilised $\mathrm{H}$. influenzae fractions expressed in $\mu \mathrm{g}$ of $\mathrm{E}$ coli endotoxin equivalents

\begin{tabular}{|c|c|c|c|c|c|c|c|c|c|c|c|}
\hline & \multicolumn{11}{|c|}{ Fractionating procedures } \\
\hline & \multirow{2}{*}{$\begin{array}{l}\text { None } \\
\text { Bacteria }\end{array}$} & \multirow{2}{*}{$\begin{array}{l}\text { Chlorof. ether } \\
\text { phenol extract } \\
\text { Endotoxin }\end{array}$} & \multirow{2}{*}{$\begin{array}{l}\text { Ultracentr. } \\
C F\end{array}$} & \multicolumn{4}{|c|}{ Sepharose $6 B$} & \multicolumn{2}{|c|}{$\begin{array}{l}\text { DEAE-Sephadex } \\
\text { A25 }\end{array}$} & \multicolumn{2}{|c|}{$\begin{array}{l}\text { Sepharose 6B } \\
\text { DEAE Sephadex } \\
\text { A25 }\end{array}$} \\
\hline & & & & Fr. I & Fr. II & Fr. III & Fr. IV & Specific & Non-specific & ic $I I I / S$ & $I I I / A S$ \\
\hline $\begin{array}{l}\text { LD }_{50} \text { in mice } \\
\text { actinomycin } \\
\text { End titration limulus }\end{array}$ & $2 \cdot 5$ & 25 & $0 \cdot 2$ & 2 & $0 \cdot 5$ & 0.03 & 0.02 & 0.07 & 2 & 0.003 & $0 \cdot 014$ \\
\hline $\begin{array}{l}\text { assay } \\
\text { Precipitins }\end{array}$ & 100 & 1000 & 1 & 1000 & $0 \cdot 1$ & $0 \cdot 1$ & $0 \cdot 1$ & $0 \cdot 1$ & $0 \cdot 1$ & 0.001 & $0 \cdot 1$ \\
\hline $\begin{array}{l}\text { Specific } \\
\text { Non-specific }\end{array}$ & $\overline{-}$ & - & $\begin{array}{l}++1 \\
+\div-4\end{array}$ & + & $\begin{array}{l}+ \\
+t+\end{array}$ & $\begin{array}{l}++4 \\
+\div\end{array}$ & $-\overline{1}$ & $\begin{array}{l}+++ \\
-\end{array}$ & $\begin{array}{l}+ \\
++i\end{array}$ & $\frac{i+}{-}$ & $\frac{1}{1+\cdots}$ \\
\hline
\end{tabular}


Each of the four main absorption maxima (I/IV) was pooled and tested for endotoxic activity and the presence of specific and non-specific precipitinogen. The main endotoxic activity was concentrated in fraction I, whereas fractions II-IV had a much lower activity. The main content of specific precipitinogen was found in fraction III. This indicated that toxicity does not depend on the presence of specific precipitinogen.

Because the separation was only partial another method was used. Immunoelectrophoresis followed by lipid and saccharide staining suggested that the charge of the lipopolysaccharide moiety was negative, as opposed to that of the positively charged specific precipitinogens (Fig. 3). Therefore ion exchange chromatography was carried out (Davies et al., 1974), using a cytoplasmic fraction.

The first eluate $(\mathrm{CP} / \mathrm{S})$ contained only the positively charged fraction. The second eluate (CP/AS) with the negatively charged fraction contained also components of the positively charged fraction. This contamination was slightly variable. When fraction III obtained by column chromatography was used in the ion exchange chromatography instead of the CF fraction a fraction (III/S) was obtained. This showed a very low endotoxic activity (Table 1) while still containing a high concentration of the specific precipitinogen as demonstrated in the immunodiffusion. It showed a reaction of identity with $H$. influenzae extract prepared as described by May (1968) (Fig. 4). It could be that endotoxin itself is a precipitinogen. Therefore endotoxin, prepared as described by Galanos et al. (1969), was tested in the immunodiffusion against sera with specific or non-specific precipitins against $H$. influenzae. No precipitate was formed. Therefore

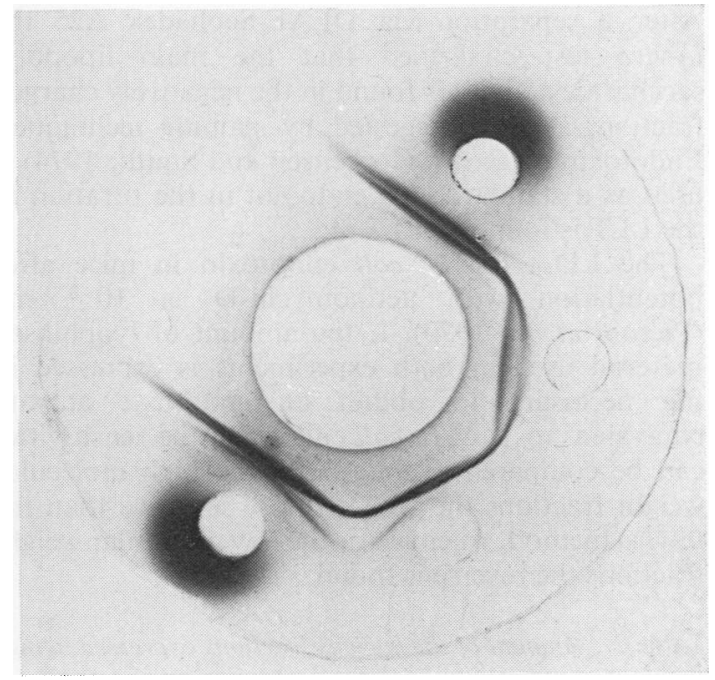

Fig. 4 Lines of identity between May antigen (two opposite wells) and purified $\mathrm{H}$. influenzae antigen (two wells in between, bottom left). Centre well contains serum of a patient with mainly specific $\mathrm{H}$. influenzae precipitins.

we concluded that endotoxin did not contribute to the precipitate as shown in Fig. 4.

COMPARISON OF METHODS USED FOR ENDOTOXIN DETECTION

In vitro the LLT shows a high endotoxic activity for the whole bacterium, the high molecular weight fraction I, and the extracted lipopolysaccharide (Table 1). The lower molecular weight fractions contain less endotoxic activity.

The in-vivo test confirmed the in-vitro findings.

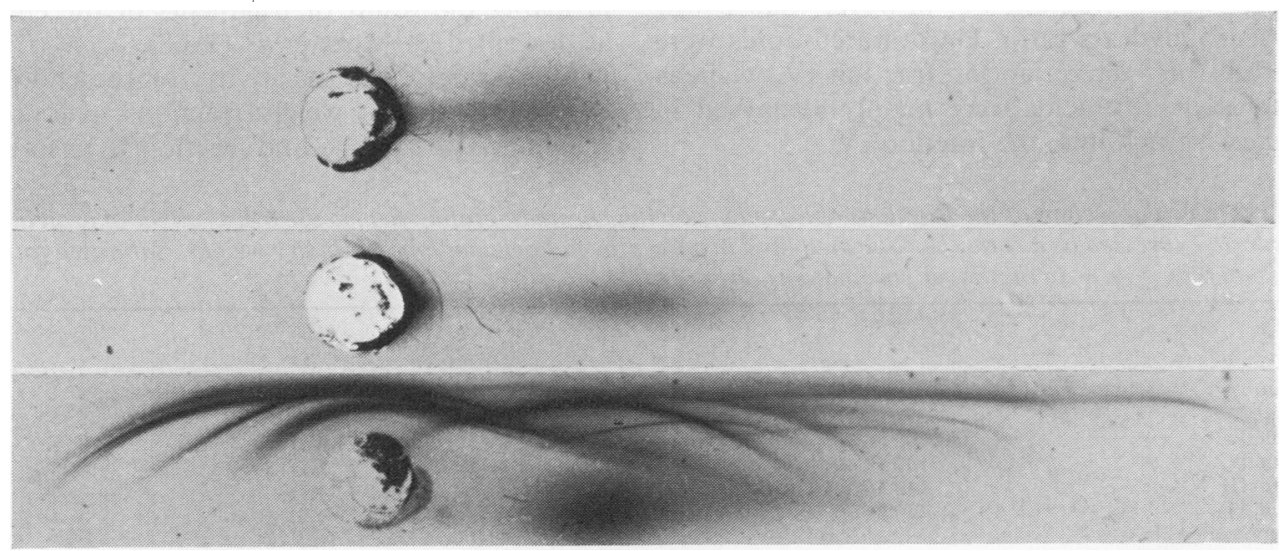

Fig. 3 From top to bottom: lipid moiety in Sudan black staining, lipopolysaccharide moiety in PAS staining, and precipitinogen content of $\mathrm{H}$. influenzae antigen after immunoelectrophoresis. 
After a separation via DEAE-Sephadex A25 the in-vivo test confirmed that the main lipopolysaccharide activity is found in the negatively charged fraction, as was suggested by staining techniques. Endotoxin of E. coli (Jorgensen and Smith, 1974) is used as a standard; the endpoint in the titration in the LLT is found at $10^{-7} \mathrm{mg}$.

The $\mathrm{LD}_{50}$ for $E$. coli endotoxin in mice after potentiation with actinomycin-D is $10^{-6} \mathrm{mg}$ (Pieroni et al., 1970). If the amount of lyophilised material used in both experiments is expressed in mg necessary to obtain an endotoxic activity equivalent to $1 \mu \mathrm{g} E$. coli endotoxin the sensitivities can be compared (Table 2). In the high molecular weight fractions the LLT is more sensitive than the in-vivo method, whereas for the low molecular weight fractions the reverse is found.

Table 2 Amount of the various fractions expressed in $\mathrm{mg}$ lyophilised material/ml solvent containing an endotoxic activity equivalent to $1 \mu \mathrm{g}$ coli endotoxin as estimated in the limulus lysate test $(L L T)$ compared with the $L D_{50}$ in mice after potentiation with actinomycin- $D$

\begin{tabular}{lllc}
\hline Compounds & $L L T$ & Mouse $L D_{50}$ & L $D_{50} / L L T$ \\
\hline Bacterium & $0 \cdot 01$ & $0 \cdot 4$ & 40 \\
Endotoxin & $0 \cdot 001$ & $0 \cdot 04$ & 40 \\
Cytopl. fraction & 1 & 5 & 5 \\
Fraction I & $0 \cdot 001$ & $0 \cdot 5$ & 500 \\
Fraction II & 10 & 20 & 2 \\
Fraction III & 10 & 30 & 3 \\
Fraction IV & 10 & 5 & $0 \cdot 5$ \\
Specific fraction & 10 & 15 & $1 \cdot 5$ \\
Non-specific fraction & 10 & $0 \cdot 5$ & $0 \cdot 05$ \\
\hline
\end{tabular}

The results of the chemical analysis and the molecular weight of the fractions are summarised in Table 3. It was shown that fraction I, II, and III had an increasing protein/carbohydrate ratio. The low molecular weight fraction IV, however, had a low protein/carbohydrate ratio. Unsaturated lipids were detected in the bacteria and in fraction IV, whereas the saturated fatty acids were mainly visualised in the bacteria, fraction I, the fraction IV.

\section{Discussion}

Gram-negative bacteria are commonly used in skin and bronchial provocation tests (Barr et al., 1965; $\underset{\sim}{\stackrel{5}{+}}$ Brown, 1934; Hajós, 1963; Hajós and Hajós, 1964; Herxheimer, 1951; Hirdes, 1969; Ricci et al., 1967). 을 Seemingly, however, no thought was given to the possibility that the reaction could be due to endo- $\stackrel{\mathbb{Q}}{\Omega}$ toxin rather than an antibody-antigen mediated reaction. For detecting endotoxin the $\mathrm{LD}_{50}$ in mice after actinomycin-D was used as an in-vivo method.

Despite the limitations of the LLT's non-specificity $\overrightarrow{\vec{U}}$ (Elin and Wolff, 1973; Stumacher et al., 1973; $\stackrel{\circ}{\circ}$ Sullivan and Watson, 1974; Wildfeuer et al., 1974; Weckesser et al., 1974) its usefulness is well estab- $\dot{\omega}$ lished (Cooper et al., 1971; Jorgensen and Smith, 1973; Levin et al., 1970). To what extent particle size $\dot{\omega}$ and electrophoretic mobility of compounds were $\partial$ related to endotoxic activity was unknown. The 음 purification of the $H$. influenzae precipitins gave us $\rightarrow$ the opportunity to find out.

To separate the specific precipitinogen from endotoxin we used the following characteristics of the $\vec{\theta}$ latter: (1) its localisation in the cell wall, (2) its high molecular weight, and (3) its electrophoretic mobility (Fig. 1). After centrifugation the supernatant proved to be contaminated with water-soluble free endo-s toxin (Jorgensen and Smith, 1974), probably due to the ultrasonic disruption. The cell wall itself was completely removed from the cytoplasmic fraction. $\stackrel{\mathbb{Q}}{2}$ The highest concentration of endotoxin was found $\overrightarrow{\vec{O}}$ in fraction I after gel filtration by Sepharose 6B.3 The fractions II-IV, however, still had a considerable endotoxic activity. Since the molecular weight of these fractions is below that of the endotoxin (Table 3) when prepared by the phenol-water? extraction (Lüderitz et al., 1966) this activity is probably the result of fragments of the endotoxin, as described by Marx et al. (1968).

Interestingly, the sensitivity for the endotoxin in the high molecular weight fractions, as found in the $H$. influenzae bacteria and fraction I, was about $10^{3} \mathrm{I}$

Table 3 Molecular weight of the fractions obtained in column chromatography Sepharose 6B. Content of protein and c'arbohydrate expressed as a ratio. Unsaturated lipid in percentage of original amount in dry weight. Saturated fatty acid graded from 0 to +++ in thin-layer chromatography

\begin{tabular}{|c|c|c|c|c|c|}
\hline Procedures & $\begin{array}{l}\text { Molecular } \\
\text { weight }\end{array}$ & $\begin{array}{l}\text { Protein } \\
(\%)\end{array}$ & $\begin{array}{l}\text { Protein/ } \\
\text { carbohydrate }\end{array}$ & $\begin{array}{l}\text { Unsaturated } \\
\text { lipids }\end{array}$ & Saturated fatty acid \\
\hline Bacterium & & 54 & $2 \cdot 1$ & 4 & $\ldots$ \\
\hline \multicolumn{6}{|l|}{ Sepharose 6B } \\
\hline Fraction I & $\geqslant 340000$ & 27 & $2 \cdot 4$ & ND & $\ldots, \ldots$ \\
\hline Fraction II & 210000 & 30 & 3.4 & ND & $\ldots$ \\
\hline Fraction III & 44000 & 52 & $11 \cdot 6$ & ND & $\ldots$ \\
\hline Fraction IV & $\leftarrow 23000$ & 7 & $1 \cdot 8$ & 2 & \\
\hline \multicolumn{6}{|l|}{ DEAE-Sephadex A25 } \\
\hline Specific fraction III S & & $24 \cdot 5$ & $2 \cdot 9$ & ND & $\ldots$ \\
\hline Non-s necific fraction III AS & & 33 & $2 \cdot 3$ & ND & \\
\hline
\end{tabular}


times higher in the LLT when compared with the toxicity in mice. This discrepancy was not found in the low molecular weight fractions II and III and only partly found in fraction IV (Table 1).

This suggests that fragmentation of the endotoxin molecule results in a diminished endotoxic activity in mice. Nowotny et al. (1975) studied a polysaccharide-rich fraction from Salmonella endotoxin with an average molecular weight of about 10000 which gave neither a mortality in mice nor a positive LLT. Ng et al. (1974), however, found a glycolipid from rough growing bacteria with a molecular weight between 15000 and 18000 with a high endotoxic activity when measured in the LLT and in mice.

The clotting reaction in the LLT is probably an enzymatic process (Young et al., 1972). The component in the lipopolysaccharide responsible for the reaction is unknown. The toxic effect in animals is caused mainly by 'lipid A' (Milner et al., 1971), but polysaccharides play an important role as well (Westphal and Lüderitz, 1954).

Tables 1 and 3 show that a compound present in fraction IV with an average molecular weight of about 23000 was still toxic for mice. The positive LLT and the potentiating effect of actinomycin-D suggest an endotoxic activity. The fraction had a very low protein/carbohydrate ratio, but some lipid compounds and unsaturated fatty acids were detectable (Table 3). The glycolipid demonstrated by $\mathrm{Ng}$ et al. (1974) might be present in this fraction and be responsible for the clotting reaction. Since we were dealing with unpurified endotoxic preparations it was impossible to correlate the chemistry with either mortality in mice or clotting properties in the LLT.

The separation obtained with the DEAE-Sephadex showed a difference in sensitivity of both test methods in the positively charged and the negatively charged fraction, which was partly caused by the insolubility of the former. This difference suggests that compounds difficult to resolve should be tested in vivo and in the LLT.

\section{Conclusion}

To discriminate between an immunological and a toxic mechanism a specific precipitinogen and endotoxin had to be prepared from $H$. influenzae. A combination of ultracentrifugation, column chromatography (Sepharose 6B), and ion exchange chromatography (DEAE-Sephadex A25) resulted in a bacterial extract that contained the specific precipitinogens and a very low endotoxic activity. Aqueous phenol, chloroform, and petroleum ether .extraction were performed to obtain endotoxin.

Both the LLT and the mortality in mice after
actinomycin-D potentiation proved to be sensitive and reproducible methods for detecting endotoxic activity in bacterial compounds. It was shown that the low molecular weight fractions from $H$. influenzae still contained endotoxic activity. The LLT proved to be more sensitive in the high molecular weight fractions, whereas the in-vivo method was more sensitive in the low molecular weight fractions. We can offer no explanation for this phenomenon. The use of both methods together seems justified.

We thank the Department of Medical Microbiology (Professor J. B. Wilterdink) and Messrs H. Jans and J. Staal for their assistance and for supplying the media. We also thank Mr B. H. P. Hazenberg for caring for the cultures, with the help of Miss E. Sluis, and doing the immunoelectrophoresis together with Miss G. Bergsma. The Limulus lysate test was carried out by $\mathrm{Mr}$ A. Feringa (Department of Hospital Epidemiology). Mr J. Berends (Central Animal Laboratory) and his staff assisted in the animal tests. Chemical analyses of the bacterial compounds were carried out with the help of Messrs W. Sluiter, L. Ruinen, J. G. Bouman, and their staff. Mr S. Pasma prepared the figures. Mrs $\mathrm{H}$. Jipping-Anholts typed the manuscript. Professor A. Kroon read it carefully and Dr Chris W. Clarke (Brisbane, Australia) revised it.

\section{References}

Barr, S. E., Brown, H., Fuchs, M., Orvis, H., Connor, A., Murray, F. J., and Seltzer, A. (1965). A double-blind study of the effects of bacterial vaccine on infective asthma. Journal of Allergy, 36, 47-61.

Branefors-Helander, P. (1973). Serological studies of Haemophilus influenzae III. The endotoxic effect of various antigen preparations and the relation between this effect and demonstrable precipitinogens. International Archives of Allergy and Applied Immunology, 44, 585-600.

Brown, G. T. (1934). The diagnosis of bacterial allergy. Southern Medical Journal, 27, 856-861.

Brumfitt, W., Willoughby, M. L. N., and Bromley, L. L. (1957). An evaluation of sputum examination in chronic bronchitis. Lancet, 2, 1306-1308.

Cooper, J. F., Levin, J., and Wagner, H. N. Jr. (1971). Qualitative comparison of in vitro and in vivo methods for the detection of endotoxin. Journal of Laboratory and Clinical Medicine, 78, 138-148.

Davies, J. L., Laughton, C. R., and May, J. R. (1974). An improved test for Haemophilus influenzae precipitins in the serum of patients with chronic respiratory disease. Journal of Clinical Pathology, 27, 265-268.

Denny, F. W. (1974). Effect of a toxin produced by Haemophilus influenzae on ciliated respiratory epithelium. Journal of Infectious Diseases, 129, 93-100.

De Petris, S. (1967). Ultrastructure of the cell wall of Escherichia coli and chemical nature of its constituent 
layers. Journal of Ultrastructural Research, 19, 45-83.

Elin, R. J., and Wolff, S. M. (1973). Nonspecifity of the limulus amebocyte lysate test: Positive reactions with polynucleotides and proteins. Journal of Infectious Diseases, 128, 349-352.

Galanos, C., Lüderitz, O., and Westphal, O. (1969). A new method for the extraction of $\mathbf{R}$ lipopolysaccharides. European Journal of Biochemistry, 9, 245-249.

Greer, G. G., Epps, N. A., and Vail, W. J. (1973). Interaction of lipopolysaccharides with mitochondria. II. Effects of magnesium ions on toxicity of a rough lipopolysaccharide. Journal of Infectious Diseases, 128, 724-729.

Hajós, K., and Hajós, M. K. (1964). Früh- und Spätreaktionen mit Bakterien-allergenen bei Bronchialasthma. Allergie und Asthma, 10, 258-263.

Hajós, M. K. (1963). Ergebnisse mit dem Inhalationstest bei Verdacht auf bakterielle und virale Sensibilisierung beim Bronchialasthma. Allergie und Asthma, 9, 94-98.

Herxheimer, H. (1951). Bronchial hypersensitization and hyposensitization in man. International Archives of Allergy and Applied Immunology, 2, 40-59.

Hirdes, J. J. (1969). Huidreacties op bacterievaccins in relatie tot de flora van de keeluitstrijk bij kinderen met een chronische astmatische bronchitis. Nederlands Tijdschrift van Geneeskunde, 113, 2121-2126.

Hoefimayr, J., and Fried, R. (1967). Erkennung von Fettstoffwechselstörungen, 1. Gesamtlipide in Serum. Medizinische Kliniek, 62, 1323-1325.

Jorgensen, J. H., and Smith, R. F. (1973). Preparation, sensitivity, and specifity of Limulus lysate for endotoxin assay. Applied Microbiology, 26, 43-48.

Jorgensen, J. H., and Smith, R. F. (1974). Measurement of bound and free endotoxin by the Limulus assay. Proceedings of the Society of Experimental Biology and Medicine, 146, 1024-1031.

Levin, J., Tomasulo, P. A., and Oser, R. S. (1970). Detection of endotoxin in human blood and demonstration of an inhibitor. Journal of Laboratory and Clinical Medicine, 75, 903-911.

Lowry, O. H., Rosebrough, N. J., Farr, A. L., and Randall, R. J. (1951). Protein measurement with the folinphenol reagent. Journal of Biological Chemistry, 193, 265-275.

Lüderitz, O., Staub, A. M., and Westphal, O. (1966). Immunochemistry of $\mathbf{O}$ and $\mathbf{R}$ antigens of Salmonella and related Enterobacteriaceae. Bacteriological Review, 30, 192-255.

Marx, A., Musetescu, M., Sedrea, M., and Milhaca, M. (1968). Relationship between particle size and biological activity of Salmonella typhimurium endotoxin. Zentralblatt für Bakteriologie I. Abt. Orig., 207, 313-316.

May, J. R. (1965). Haemophilus influenzae antigenantibody reactions. Journal of Pathology and Bacteriology, 90, 379-392.

May, J. R. (1968). The Chemotherapy of Chronic Bronchitis and Allied Disorders, p. 97. English Universities Press, London.

Milner, K. C., Rudbach, J. A., and Ribi, F. (1971). General characteristics (of bacterial toxins). In Microbial Toxins, Vol. IV, Bacterial Toxins, edited by G. Weinbaum, S. Kadis and S. J. Ajl.
Mulder, J. (1938). Haemophilus influenzae (Pfeiffer) as an ubiquitous cause of common acute and chronical purulent bronchitis. Acta Medica Scandinavica, 94, 98-140.

Ng, A. K., Chang, C. M., Chen, C. H., and Nowotny, A. (1974). Comparison of the chemical structure and biological activities of the glycolipids of Salmonella minnesota R 595 and Salmonella typhimurium SL 1102. Infection and Immunity, 10, 938-947.

Nowotny, A., Behling, U. H., and Chang, H. L. (1975). Relation of structure to function in bacterial endotoxins. VIII. Biological activities in a polysaccharide-rich fraction. Journal of Immunology, 115, 199-203.

Omland, T. (1964). Serological studies on Haemophilus influenzae and related species. 8. Examinations of ultrasonically prepared Haemophilus antigens by means of immunoelectrophoresis. Acta Pathologica Microbiologica Scandinavica, 62, 89-106.

Ouchterlony, O. (1962). Diffusion-in-gel methods for immunological analysis. II. Progress in Allergy, 6, 30-154.

Pieroni, R. E., Broderick, E. J., Bundeally, A., and Levine, L. (1970). A simple method for the quantitation of submicrogram amounts of bacterial endotoxin. Proceeding of the Society of Experimental Biology and Medicine, 133, 790-794.

Reed, L. J., and Muench, H. (1938). A simple method of estimating fifty per cent endpoints. American Journal of Hygiene, 27, 493-497.

Ricci, M., Fischlewitz, J., Ricca, M., and Passaleva, A. (1967). A study on bacterial sensitization in the infective asthma. Acta Allergologica, 22, 47-56.

Rojas-Corona, R. R., Skarnes, R., Tamakuma, S., and Fine, J. (1969). The limulus coagulation test for endotoxin: a comparison with other assay methods. Proceedings of the Society of Experimental Biology and Medicine, 132, 599-601.

Stumacher, R. J., Kovnat, M. J., and McCabe, W. R. (1973). Limitations of the usefulness of the Limulus assay for endotoxin. New England Journal of Medicine, 288, $1261-1264$.

Sullivan, J. D., Jr. and Watson, S. W. (1974). Factors effecting the sensitivity of Limulus lysate. Applied Microbiology, 28, 1023-1026.

Toennies, G., and Kolb, J. J. (1964). Carbohydrate analysis of bacterial substances by a new anthrone procedure. Analytical Biochemistry, 8, 54-69.

Uriel, J. (1964). Immuno-electrophoretic Analysis, edited by P. Grabar and P. Burtin, p. 48. Elsevier, Amsterdam.

Weckesser, J., Katz, A., Drews, G., Mayer, H., and Fromme, I. (1974). Lipopolysaccharide containing L-acofriose in the filamentous blue-green alga Anabaena variabilis. Journal of Bacteriology, 120, 672-678.

Westphal, O., and Lüderitz, O. (1954). Chemische Erforschung von Lipopolysacchariden gramnegativer Bakterien. Angewendte Chemie, 66, 407-417.

Wildfeuer, A., Heymer, B., Schleifer, K. H., and Haferkamp, O. (1974). Investigations on the specifity of the Limulus test for the detection of endotoxin. Applied Microbiology, 28, 867-871. 
Young, N. S., Levin, J., and Prendergast, R. A. (1972). An invertebrate coagulation system activated by endotoxin: evidence for enzymatic mediation. Journal of Clinical Investigation, 51, 1790-1797.

Zoon, K. C., and Scocca, J. J. (1975). Constitution of the cell envelope of Haemophilus influenzae in relation to competence for genetic transformation. Journal of Bacteriology, 123, 666-677.

Zwan, J. C. van der, Orie, N. G. M., and Vries K. de (1975). Biphasic reaction after inhalation of Haemophilus influenzae in patients with chronic nonspecific lung disease. Clinical Allergy, 5, 225-232.

\section{The March 1978 Issue}

\section{THE MARCH 1978 ISSUE CONTAINS THE FOLLOWING PAPERS}

Ultrastructure of Ebola virus particles in human liver D. S. ELLIS, D. I. H. SIMPSON, D. P. FRANCIS, J. KNOBLOCH, E. T. W. BOWEN, PACIFICO LOLIK, AND ISAIAH MAYOM DENG

Evaluation of the Microcult system for isolating and identifying Neisseria gonorrhoeae R. J. WILLIAMS, C. S. RATNATUNGA, J. M. T. HAMILTON-MILLER, AND W. BRUMFITT

Chemotactic activity of cerebrospinal fluid in pyogenic meningitis B. M. GREENWOOD

Outbreak of infantile enteritis caused by enterotoxigenic Escherichia coli O6.H16 B. ROWE, R. J. GROSS, S. M. SCOTLAND, A. E. WRIGHT, G. N. SHILLOM, AND N. J. HUNTER

Flavobacterium meningosepticum as an opportunist RAMA M. MANI, K. C. KURUVILA, P. M. BATLIWALA, P. N. DAMLE, G. V. SHIRGAONKAR, R. P. SONI, AND P. R. VYAS

Some interesting isolates from a diagnostic laboratory P. L. LIM

Effect of Tween 80 on incubation period of Lactobacillus casei assay of serum folate G. B. TENNANT

Polyene antibiotics in assessing significance of antistreptolysin $O$ activity $K$. C. WATSON AND E. J. C. KERR

Paraganglioneuroma of the duodenum: an evolutionary hybrid? T. COONEY AND E. C. SWEENEY

Significance of $\alpha$-subunit HCG demonstrated in breast carcinomas by the immunoperoxidase technique ROSEMARY A. WALKER

IgM lambda cytoplasmic crystals in three cases of immunocytoma: a clinical, cytochemical, and ultrastructural study W. W. FEREMANS, P. NEVE, AND M. CAUDRON

Copies are still available and may be obtained from the PUBLISHING MANAGER, BRITISH MEDICAL ASSOCIATION, TAVISTOCK SQUARE, LONDON WC1H $9 \mathrm{JR}$, price $£ 3.00$, including postage
Cerebral involvement in multiple myeloma: case report J. MCCARTHY AND S. J. PROCTOR

Congenital syphilis in aborted second trimester fetus: diagnosis by histological study HERBERT BRAUNSTEIN

Internal sphincter and haemorrhoids : a pathological study M. T. HAQQANI AND B. D. HANCOCK

Abridged differential leucocyte counts provided by a Coulter Channelyzer in a routine haematology laboratory PATRICIA A. WYCHERLEY AND M. J. O'SHEA

International Committee for Standardization in Haematology: Protocol for type testing equipment and apparatus used for haematological analysis

Staining properties and stability of a standardised Romanowsky stain P. N. MARSHALL, S. A. BENTLEY,

Measuring IgG anti-A/B titres using dithiothreitol (DTT) R. C. KNIGHT

\section{Technical methods}

A multiple sampling device for the mass screening of serum samples for hepatitis B surface antigen C. H. CAMERON AND J. A. J. BARBARA

An immunofluorescent method for detecting antibodies against viridans streptococci in Streptococcus viridans endocarditis D. C. SHANSON AND CAROL HINCE

Letters to the Editor

Book reviews AND S. M. LEWIS 